\title{
UPAYA MENINGKATKAN PENERIMAAN DIRI (SELFACCEPTANCE) SISWA MELALUI KONSELING INDIVIDU DENGAN PENDEKATAN REALITA KELAS XI SMA NEGERI 15 BANDAR LAMPUNG
}

\author{
RATNA BR KARO SEKALI, AHMAD TOHIR
}

\begin{abstract}
ABSTRAK
Tujuan penelitian ini adalah untuk mengetahui apakah self acceptance siswa kelas XI dapat diubah melalui konseling individu realita. Penelitian ini termasuk dalam jenis penelitian eksperimen dengan desain penelitian one group pre-test and post-test design. Subyek penelitian ini adalah 6 siswa kelas XI SMA Negeri 15 Bandar Lampung yang memiliki self acceptance rendah dan memenuhi beberapa kriteria dalam subyek penelitian. Pemilihan subyek penelitian berdasarkan hasil wawancara terhadap guru pembimbing serta siswa. Sebelum dan setelah pemberian treatment. Analisis data menggunakan teknik analisis data deskriptif persentase dan uji wilcoxon. Hasil penelitian menunjukan bahwa self acceptance siswa sebelum mendapatkan konseling individu realita termasuk dalam kriteria rendah dengan persentase $48 \%$. Setelah mendapatkan konseling individu realita mengalami peningkatan menjadi $64 \%$ dengan kriteria sedang. Dengan demikian terjadi perubahan positif sebesar $16 \%$. Hasil perhitungan uji wilcoxon sebelum dan setelah mendapatkan treatment, diperoleh Zhitung=2,20>Ztabel= 0 dengan taraf signifikansi 5\% sehingga dinyatakan bahwa Ha diterima. Dengan kata lain bahwa konseling individu realita dapat mengubah self acceptance rendah pada siswa kelas XI SMA Negeri 15 Bandar Lampung.
\end{abstract}

Kata kunci: konseling individu, realita, self acceptance,

\section{PENDAHULUAN}

Dalam menjalani proses kehidupannya, individu selalu berusaha mencari dan menemukan apa yang disebut dengan kebahagiaan. Berkaitan dengan hal tersebut Shaver dan Friedman dalam Hurlock (2014: 19) menyebutkan bahwa: “beberapa esensi kebahagiaan atau keadaan sejahtera, kenikmatan atau kepuasan, di antaranya adalah sikap menerima (acceptance), kasih sayang (affection), dan prestasi (achievement)". Selanjutnya Al-Mighwar (2016: 49) menyebutkan bahwa: "penerimaan adalah faktor yang penting dalam kebahagiaan, baik penerimaan diri sendiri maupun penerimaan sosial". Berdasarkan hal tersebut dapat diketahui bahwa dalam mencapai kebahagiaan, individu harus memiliki penerimaan diri (self acceptance).

Menurut Husniyati (2016: 4) "Individu yang mempunyai penerimaan diri rendah akan mudah putus asa, selalu menyalahkan dirinya, malu, rendah diri akan keadaannya, merasa tidak berarti, merasa iri terhadap keadaan orang lain, akan sulit membangun hubungan positif dengan orang lain, dan tidak bahagia". Siswa yang 
tidak memiliki penerimaan diri yang baik akan sangat rentan menjadi tertekan dan mengalami kesulitan dalam memusatkan konsentrasi pikiran, melamahkan motivasi dan daya juang anak. Pada akhirnya anak tidak mampu mengaktualisasikan kemampuannya dalam mengembangkan dirinya dengan baik.

Setiap individu termasuk siswa SMA Negeri 15 Bandar Lampung seharusnya memiliki self acceptance yang baik, namun pada kondisi yang ada di lapangan ternyata masih dijumpai siswa yang memiliki penerimaan diri rendah. Hal tersebut dapat diketahui dari data awal yang merupakan hasil analisis perbutir inventori DCM (daftar cek masalah) pada kelas XI sejumlah 34 siswa sebagai berikut: (1) "saya tidak suka bergaul dengan orang yang kedudukannya lebih tinggi", persentase (32,29\%/12 anak), derajad permasalahan D; (2) "saya merasa iri hati atas prestasi orang lain", persentase (44,12\%/15 anak), derajad permasalahan D; (3) "sering menyesali diri sendiri", persentase (79,41\%/27 anak), derajad masalah E; (4) "saya ingin tampak lebih menarik", persentase (61,76\%/21 anak), derajad masalah E; (5) "saya merasa diri saya tidak sebaik orang lain", persentase (67,65\%/23 anak), derajad masalah E; (6) "saya mudah tersinggung", persentase (64,70\%/ 22 anak), derajat permasalahan E; (7) "sering bertentangan pendapat dengan orang lain", persentase (61,76\% / 21 anak), derajat permasalahan E.

Pada fenomena di lapangan, rendahnya penerimaan diri pada siswa ini ditemukan oleh peneliti di SMA Negeri 15 Bandar Lampung khususnya pada siswa kelas XI. Secara garis besar fenomena yang dialami oleh siswa yang berlatarbelakang ekonomi lemah dan hambatan-hambatan ketika berinteraksi dalam pergaulan dan ketika sedang berada di dalam kelas. Gejala-gejala rendahnya penerimaan diri yang dijumpai oleh peneliti dalam fenomena di lapangan yakni rasa minder dalam pergaulan, sikap menghindar dari teman sekelas dan ragu akan bagaimana dirinya menghadapi masa depan.

Dari hasil wawancara awal dengan guru bimbingan dan konseling didapat informasi yakni ada 2 siswa yang datang menemui guru bimbingan dan konseling mengaku malu dengan kekurangan dan keadaan dirinya yang tidak sama seperti teman-teman lainnya dan siswa-siswa tersebut juga mengaku sangat ingin bisa menjadi seperti teman-teman lainnya. Kemudian dalam proses interaksi belajar mengajar, siswa menjadi cenderung pasif dan menjawab seadanya ketika menjawab pertanyaan yang dilontarkan Guru di kelas.

Berdasarkan hasil wawancara dengan guru bimbingan dan konseling, diketahui ada 1 siswa yang tinggal di kelas XI. Setelah melihat raport memang benar mereka adalah siswa tinggal kelas dan mendapatkan nilai di bawah kriteria ketuntasan minimal (KKM). Berdasarkan hasil wawancara dengan guru bimbingan dan konseling, siswa yang mengalami masalah rendahnya kepercayaan diri setelah mengalami kegagalan studi dan perlu segera mendapat penanganan lebih lanjut, yaitu UL. 
Berdasarkan fenomena tersebut, untuk mengatasi rendahnya penerimaan diri pada siswa kelas XI maka melalui pendekatan realita dianggap sesuai. Pendekatan realita berfokus pada hakekat manusia yang pada dasarnya memilih perilakunya sendiri maka individu bertanggung jawab, bukan hanya pada apa yang dilakukan tetapi juga pada sesuatu yang dipikirkan. Konseling realita menitikberatkan tanggung jawab yang dipikul konseli agar konseli berperilaku sesuai dengan realitas atau kenyataan yang dihadapi. Penyimpangan dalam tingkah laku konseli dipandang sebagai akibat dari tidak adanya kesadaran mengenai tanggung jawab pribadi, bukan sebagai indikasi/gejala adanya gangguan dalam kesehatan mental. Menurut Glasser dalam Winkel (2007: 459), “bermental sehat adalah menunjukkan rasa tanggung jawab dalam semua perilaku, orang-perorangan tidak diperkenankan untuk bertindak sesuka hati, dia harus menunjukkan tingkah laku yang tepat dan menghindari tingkah laku yang salah (right and wrong behavior)". Pada konseling realita, perilaku bermasalah dapat disepadankan dengan istilah yang dikemukakan Glasser dalam Latipun (2015: 128), yaitu “identitas kegagalan". Identitas kegagalan itu ditandai dengan keterasingan, penolakan diri dan irrasionalitas, perilakunya kaku, tidak objektif, lemah, tidak bertanggung jawab, kurang percaya diri dan menolak kenyataan. Seperti halnya fenomena dalam penelitian ini siswa tinggal kelas yang memiliki penerimaan diri rendah, siswa cenderung mengembangkan identitas kegagalan dan sulit menerima kenyataan yang dialaminya.

Pendekatan realita berasumsi bahwa realisasi untuk tumbuh dalam rangka memuaskan kebutuhan harus dilandasi oleh prinsip 3R, yaitu right (mempelajari apa yang benar), responsibility (bertingkahlaku secara bertanggung jawab) dan reality (memahami serta menghadapi kenyataan). Menurut Latipun (2005: 109) secara umum tujuan konseling realita sama dengan tujuan hidup, yaitu individu mencapai kehidupan dengan success identity. Dalam hal ini identitas keberhasilannya adalah memiliki kepercayaan diri pada siswa tinggal kelas. Pendekatan realita bertujuan memberikan kemungkinan dan kesempatan kepada konseli agar bisa mengembangkan kekuatan-kekuatan psikis yang dimilikinya untuk menilai perilakunya sekarang dan apabila perilakunya tidak dapat memenuhi kebutuhan, maka perlu memperoleh perilaku baru yang lebih efektif.

Berdasarkan hal tersebut, perlu dilakukan usaha untuk mengatasi rendahnya penerimaan diri siswa. Rendahnya penerimaan diri ini diharapkan dapat diatasi melalui konseling realita dengan melakukan perencanaan yang rinci, matang dan tersusun secara sistematis, serta persiapan yang cukup (baik secara fisik, mental/pun emosional) dan apresiasi terhadap kelebihan dan kemampuan yang dimiliki. Konseli dibantu merumuskan tingkah laku apa yang akan diperbuatnya. Dengan demikian, konseli dapat mengungkapkan harapan dan keinginannya, dapat berperilaku yang bertanggung jawab, yang pada akhirnya dapat merubah anggapan buruk tentang dirinya sendiri yang tidak berguna dan lebih optimis dalam menatap masa depan.

Chaplin (2010:450) menambahkan bahwa "penerimaan diri adalah sikap yang pada dasarnya merasa puas dengan diri sendiri, kualitas-kualitas dan bakat-bakat sendiri, 
dan pengakuan akan keterbatasan-keterbatasan sendiri." Penerimaan diri dalam hal ini mengandung makna bahwa individu bisa menghargai segala aspek yang ada pada dirinya entah itu yang bersifat positif maupun yang bersifat negatif.

Individu yang memiliki self acceptance akan memandang kelemahan/kekurangan diri sebagaai hal yang wajar dimiliki setiap individu, karena individu yang memiliki self acceptance akan bisa berpikir positif tentang dirinya bahwa setiap individu pasti memiliki kelemahan/kekurangan dan hal tersebut tidak akan menjadi penghambat individu untuk mengaktualisasikan dirinya. Sebagai contoh, siswa yang berasal dari golongan keluarga berekonomi rendah tidak merasa canggung berteman/bergaul dengan siswa lain yang berasal dari golongan keluarga ekonomi atas, karena siswa tersebut menyadari bahwa semua siswa mempunyai hak dan kewajiban yang sama di sekolah.

Konsep yang lebih jelas dikemukakan oleh Helmi (dalam Nurviana, 2010: 04 ) yang mengartikan "penerimaan diri adalah sejauh mana seseorang dapat menyadari dan mengakui karakteristik pribadi dan menggunakannya dalam menjalani kelangsungan hidupnya". Sikap penerimaan diri ditunjukan oleh pengakuan seseorang terhadap kelebihan-kelebihan sekaligus menerima kelemahankelemahannya tanpa menyalahkan orang lain dan mempunyai keinginan yang terus-menerus untuk mengembangkan diri.

Dari pengertian-pengertian di atas dapat disimpulkan bahwa penerimaan diri adalah suatu sikap dimana individu memiliki penghargaan yang tinggi terhadap segala kelebihan dan kekurangan dirinya sendiri tanpa menyalahkan orang lain dan mempunyai keinginan untuk mengembangkan diri secara terus menerus.

Konseling realita memiliki tujuan yang ingin dicapai. Tujuan konseling realita terbagi menjadi tujuan umum dan tujuan khusus. Tujuan umum konseling realita adalah :

a. Membantu individu mencapai otonomi

b. Membantu individu dalam menentukan dan memperjelas tujuan individu.

c. Membantu individu menemukan alternatif-alternatif dalam mencapai tujuan-

tujuan, namun individu tersebut yang menetapkan tujuan-tujuan terapi ini.

Sedangkan tujuan khusus dari konseling realita harus diungkapkan dari segi konsep tanggung jawab individual alih-alih dari segi tujuan-tujuan bagi dirinya sendiri. Hal ini seperti yang dikemukakan Corey (2016: 270) "klien dituntut bertanggung jawab dalam pemenuhan tujuan-tujuan klien dalam melaksanakan rencana-rencananya secara mandiri." Tujuan konseling realita menurut Fauzan (1994: 35-36) adalah:

1) Membantu individu mencapai otonomi.

2) Membantu individu dalam mengartikan dan memperluas tujuan-tujuan hidup mereka.

3) Membantu individu menemukan kebutuhannya dengan prinsip 3R, yaitu Right, responsibility dan reality. 
Glasser (dalam Corey, 2007: 269) menyebutkan bahwa "mengajarkan tanggungjawab merupakan inti dalam konseling realita." Tujuan umum terapi realita adalah membantu seseorang untuk mencapai otonomi. Pada dasarnya, otonomi adalah kematangan yang diperlukan bagi kemampuan seseorang untuk mengganti dukungan lingkungan dengan dukungan internal. Kematangan inimenyiratkan bahwa orang-orang mampu bertanggungjawab atas siapa mereka dan ingin menjadi apa mereka serta mengembangkan rencana-rencana yang bertanggungjawab individual dari segi tujuan-tujuan realita karena klien harus menentukan tujuan-tujuan itu bagi dirinya sendiri.

Berdasarkan uraian tersebut maka peneliti berkeinginan untuk melakukan penelitian dengan judul "Meningkatkan Penerimaan Diri (Self Acceptance) Siswa Melalui Konseling Individu dengan Pendekatan Realita di SMA Negeri 15 Bandar Lampung Kelas XI Tahun Ajaran 2019/2020". Tujuan yang ingin dicapai dalam penelitian ini adalah untuk mengetahui apakah self acceptance dapat ditingkatkan melalui layanan konseling individu pendekatan realita pada siswa kelas XI SMA Negeri 15 Bandar Lampung

\section{METODE PENELITIAN}

Metode penelitian diantaranya (1) Jenis penelitian, (2) Desain penelitian, (3) Variabel penelitian, (4) Populasi dan subyek, (5) Alat pengumpul data, (6) Validitas dan reliabilitas, (7) Teknik analisis data. Dalam penelitian ini, menggunakan jenis penelitian eksperimen. Metode yang digunakan dalam penelitian dalam penelitian ini adalah one group pre-test and post test design berarti subjek penelitian diberikan tes sebelum dan sesudah mendapatkan perlakuan tertentu. Dalam penelitian ini subjek dikenakan dua kali pengukuran. Pengukuran yang pertama dilakukan untuk mengukur. Dalam penelitian ini populasi yang dimaksud adalah seluruh siswa kelas XI SMA Negeri 15 Bandar Lampung yang memiliki self acceptance rendah dan sangat rendah. Jumlah populasi yang digunakan dalam penelitian ini yaitu siswa dengan karakteristik khusus yang mempunyai penerimaan diri yang rendah dan sangat rendah. Penjaringan siswa yang memiliki karakteristik penerimaan diri yang rendah dilakukan dengan menggunakan skala psikologis dengan jumlah siswa sesuai hasil skala psikologis dengan skor yang masuk dalam kriteria memiliki penerimaan diri yang rendah. Metode pengumpulan data yang digunakan dalam penelitian ini adalah skala psikologi dan wawancara.

\section{HASIL DAN PEMBAHASAN}

Treatment dalam penelitian ini berupa konseling individu realita yang dilaksanakan dalam tiga tahapan tatap muka. Petemuan diawali dengan melakukan pembinaan hubungan baik (rapport), pre test, kemudian dilanjutkan pertemuan konseling maksimal 5 kali pertemuan atau sesuai kebutuhan, dan yang terakhir dilakukan post test serta pengakhiran. Dalam setiap pertemuan konseling individu membahas 
permasalahan pribadi yang dialami oleh siswa kelas XI. Pelaksanaan layanan konseling individu dilakukan kurang lebih 30-40 menit dan dilakukan penilaian segera oleh peneliti. Setelah melakukan proses konseling individu selama beberapa kali dapat dilihat perkembangan terhadap perilaku konseli dilatarbelakangi permasalahan yang berbeda-beda. Ada permasalahan yang menyangkut lingkungan keluarga, pergaulan, sekolah dan bahkan pribadi konseli sendiri. Dalam hal ini konselor berusaha untuk memberikan treatment kepada konseli agar penerimaan dirinya meningkat sehingga konseli dapat belajar dari pengalamannya

Pada proses konseling ini akan digambarkan secara singkat setiap pertemuan dengan klien.

1. Pre-test

Pada pertemuan pertama, klien terlebih dahulu diminta untuk mengisi skala penerimaan diri yang terlebih dahulu dibacakan petunjuk pengisiannya oleh praktikan dan klien diminta mengisikan secara jujur sesuai dengan keadaan yang mereka hadapi atau yang mereka alami saat ini yang berhubungan dengan masalah penerimaan diri. Tujuan dari pengisian skala penerimaan diri adalah untuk mengetahui bagaimana gambaran penerimaan diri yang dialami klien sebelum diberikan perlakuan.

2. Tahap I (Assesment)

Assesment merupakan awal dimulainya kegiatan konseling. Pada tahap ini, pertemuan dimulai dengan pembentukkan rapport antara praktikan dengan klien agar tujuan dari proses konseling bisa tercapai. Praktikan memantapkan kesediaan klien untuk dibantu mengatasi masalah yang dialami sehingga klien bisa mengungkapkan masalah yang dialaminya dengan sukarela tanpa ada unsur paksaan.

Sebelum memulai proses konseling, terlebih dahulu dilakukan pembentukan rapport antara praktikan dengan klien. Praktikan memulai pembicaraan dengan topik diluar permasalahan klien yaitu tentang pelajaran dan tugas-tugas sekolah, agar mencairkan suasana. Praktikan berupaya agar klien bisa terbuka dalam mengungkapkan masalah yang dihadapi dengan jalan menjelasakan maksud dan tujuan dari kegiatan konseling. Diharapkan dalam pertemuan ini praktikan mendapatkan data atau informasi secara lengkap sehingga bermanfaat untuk proses konseling selanjutnya.

Dalam tahap ini, klien menjelaskan bahwa ia memiliki penerimaan diri yang rendah terutama dalam pergaulan di sekolah, ia malu dengan kondisi latar belakang dirinya. Klien merasa iri dengan segala fasilitas yang dimiliki oleh teman-temannya jika dibandingkan dengan kondisi yang dialami dirinya. Hal inilah yang membuat klien menjadi anak yang sulit untuk bergaul. Klien mengatakan ia memiliki penerimaan diri yang rendah karena klien merasa malu dengan latar belakang ekonomi orang tuanya oleh sebab itu ia merasa malu saat berkumpul dengan teman sekelasnya walaupun hanya untuk sekedar bermain pada saat jam istirahat.

$\underline{\text { Evaluasi : }}$ 
Evaluasi hasil pertemuan tahap I adalah klien sudah bisa terbuka dalam menceritakan masalah yang dihadapinya kepada praktikan. Klien merasa senang dan terbantu dengan adanya kegiatan konseling tersebut.

\section{Tahap II (Wants and needs)}

Sesuai dengan tahapan kedua dalam konseling realita adalah eksplorasi keinginan, kebutuhan, serta persepsi konseli. Terlebih dulu peneliti menanyakan kesiapan konseli untuk melaksanakan konseling. Kemudian konseli melakukan kontrak waktu terhadap konseli dan kemudian disepakati bahwa konseling akan dilaksanakan kurang lebih selama 40 menit. Sebelum menuju pada tahap selanjutnya, peneliti mengadakan sedikit evaluasi dari pertemuan sebelumnya mengenai masalah rendahnya penerimaan diri konseli, yaitu konseli malu dengan kondisi latar belakang dirinya. Klien iri dengan segala fasilitas yang dimiliki oleh teman-temannya jika dibandingkan dengan kondisi yang dialami dirinya. Hal inilah yang membuat klien menjadi anak yang sulit untuk bergaul, sehingga membuat konseli menarik diri dari pergaulan.

Peneliti mulai mengeksplorasi kebutuhan, keinginan dan persepsi konseli. Konseli mengungkapkan keinginannya untuk berubah menjadi pribadi yang memiliki penerimaan diri yang baik, menjadi pribadi yang lebih baik karena konseli menyadari bahwa self acceptance adalah pondasi untuk bisa menjadi orang yang sukses. Konseli mengatakan ingin dapat bergaul dengan teman-temannya sehingga bisa semangat ketika pergi ke sekolah, konseli ingin dapat meningkatkan penerimaan dirinya dalam pergaulan sehingga memiliki banyak teman, sehingga ini bisa membuatnya lebih semangat dan menjadi motivasi ketika di sekolah.

Kontrak waktu selama 40 menit telah habis, peneliti mengakhiri konseling pada pertemuan tersebut dengan menanyakan pemahaman, perasaan dan apa yang akan dilakukan konseli setelah mengikuti konseling (UCA: understanding, comfort, and action) kepada konseli. Peneliti menanyakan kesediaan konseling pada pertemuan berikutnya dan disepakati bahwa pertemuan selanjutnya akan dilaksanakan di ruang BK lagi.

\section{Hasil konseling:}

Konseli sudah mulai terbuka untuk mengungkapkan apa yang menjadi keinginan, kebutuhan dan persepsi yang konseli harapkan selama ini. Konseli ingin menjadi pribadi yang lebih baik lagi dan lebih bisa menerima dirinnya yang berkaitan dengan latar belakang kondisi keluarganya.

\section{Tahap III (Direction and Doing)}

Pertemuan ketiga adalah eksplorasi arah dan tindakan. Konseli mulai terbiasa dan akrab dengan kehadiran peneliti. Peneliti memulai konseling dengan berbincang-bincang topik netral dan mengadakan kontrak waktu. Pertemuan kali ini 
disepakati konseling dilaksanakan selama 40 menit. Sebelum menuju pada tahap selanjutnya, peneliti mengadakan sedikit evaluasi dari pertemuan sebelumnya. Selanjutnya peneliti menanyakan pada konseli perilaku yang selama ini dilakukan berhubungan dengan masalah rendahnya penerimaan diri yang dialaminya. Konseli merasa malu dengan latar belakang ekonomi orang tuanya oleh sebab itu ia merasa malu saat berkumpul dengan teman sekelasnya walaupun hanya untuk sekedar bermain pada saat jam istirahat. Konseli memilih untuk menarik diri dalam bergaul karena malu dan rendah diri pada teman-temannya yang berasal dari keluarga yang mampu secara ekonomi, bila tidak diajak mengobrol duluan, konseli diam saja. Selain itu, konseli juga pasif saat proses belajar mengajar di kelas. Konseli tidak berani berbicara dengan teman lawan jenis. Konseli grogi dan tidak memandang teman-temannya saat berada di kelas. Perilaku-perilaku tersebut terus-menerus dilakukan sehingga merugikan diri konseli sendiri, bahkan berdampak pada nilainya yang semakin menurun. Namun, konseli kesulitan untuk merubah perilakunya tersebut.

Kontrak waktu selama 40 menit telah habis, peneliti mengakhiri konseling pada pertemuan tersebut dengan menanyakan pemahaman, perasaan dan apa yang akan dilakukan konseli setelah mengikuti konseling (UCA: understanding, comfort, and action) kepada konseli. Peneliti menanyakan kesediaan konseling pada pertemuan berikutnya dan disepakati bahwa pertemuan selanjutnya akan dilaksanakan di ruang BK lagi.

\section{Hasil konseling:}

Hasil konseling pada pertemuan ketiga tersebut adalah konseli melakukan perilakuperilaku yang merugikan dirinya dan membuatnya semakin tidak bisa menerima dirinya. Namun, konseli kesulitan untuk merubah perilakunya tersebut.

\section{Tahap IV (Evaluation)}

Tahap keempat merupakan evaluasi diri. Dalam tahap ini peneliti mengajak konseli untuk bersama-sama melakukan evaluasi atau melakukan penilaian terhadap tingkah laku konseli yang selama ini dilakukannya dan berhubungan dengan rendahnya penerimaan diri yang dialami konseli. Peneliti terlebih dahulu melakukan kontrak waktu dengan konseli dan menyepakati bahwa waktu yang akan digunakan untuk konseling pada pertemuan tersebut adalah 15 menit.

Tindakan-tindakan tersebut antara lain:

1. Konseli mengevaluasi perilakunya yang minder dalam bergaul dengan teman sekelasnya dan lebih cenderung menarik diri dalam pergaulan di lingkungan sekolah. Bahkan dengan teman sekelasnyanya, konseli juga jarang berkomunikasi. Konseli merasa menjadi siswa yang paling menderita di kelasnya membuat konseli kurang bersemangat saat di kelas. Namun, konseli menyadari bahwa apa yang dilakukan konseli tersebut adalah keliru, seharusnya konseli bisa aktif berkomunikasi dengan teman dan menghilangkan rasa minder dan pikiran negatif tentang dirinya yang berangkat dari latar 
belakang kondisi ekonomi keluarganya. Konseli menyadari bahwa rasa penerimaan diri pada teman sebaya sangat penting bagi anak seusianya. Memiliki banyak teman akan bermanfaat karena dapat saling berbagi, menghargai dan dapat membantu dikala konseli mendapatkan masalah dan saat menemui kesulitan dalam pelajaran.

2. Konseli mengevaluasi bahwa sikapnya yang pasif saat proses belajar mengajar di kelas akan merugikan diri konseli sendiri. Konseli menyadari bahwa rasa malu, tidak yakin dengan kemampuannya dan tidak berani saat ingin bertanya dengan guru dan saat berbicara di depan kelas semakin membuatnya tidak percaya diri dan menyebabkan nilai konseli turun. Konseli menyadari bahwa tindakannya akan membuat konseli kurang bersemangat saat di kelas dan menghambat tercapainya keinginan dan kebutuhan konseli sehingga semakin membuat konseli tidak bisa menerima dirinya.

Kontrak waktu selama 15 menit telah habis, peneliti mengakhiri konseling pada pertemuan tersebut dengan menanyakan pemahaman, perasaan dan apa yang akan dilakukan konseli setelah mengikuti konseling (UCA: understanding, comfort, and action) kepada konseli. Peneliti menanyakan kesediaan konseling pada pertemuan berikutnya dan disepakati bahwa pertemuan selanjutnya akan dilaksanakan di ruang BK.

\section{Hasil konseling:}

Konseli dapat menilai tingkah lakunya sendiri dan menyadari bahwa tindakan yang selama ini dilakukannya menghambat tercapainya keinginan dan kebutuhan konseli dan semakin membuat konseli tidak bisa menerima dirinya, untuk itu konseli berkomitmen untuk berusaha merubah tindakannya yang kurang baik. Konseli terlihat lebih nyaman dengan peneliti, hal ini dapat dirasakan dari sikap konseli yang lebih terbuka terhadap peneliti.

\section{Tahap V (Planning)}

Peneliti melakukan konseling pada pertemuan kelima ini dengan melakukan kontrak waktu yang disepakati selama 40 menit dan mengingatkan konseli tentang hasil konseling pada pertemuan sebelumnya untuk memudahkan konseling pada tahap ini. Pada tahap ini konseli membuat rencana tindakan yang sesuai dengan keinginannya sendiri, sederhana, mudah dilakukan dan dilaksanakan terus-menerus untuk mencapai tujuan yang diinginkan. Rencana dan tindakan dibuat oleh konseli bersama dengan peneliti. Peneliti membantu konseli dalam menyusun rencana dan tindakannya agar sesuai dengan tujuan yang ingin dicapai olehnya.

Konseli menyusun rencana tindakan dengan bantuan peneliti untuk mencapai tujuan yang diinginkan, yaitu:

1. Untuk mengatasi rasa minder dalam bergaul dengan teman sekelasnya, konseli akan mencoba terlebih dahulu menyapa teman bila bertemu. Konseli akan 
mencoba bergabung dan mengajak mengobrol teman-temannya ketika jam istirahat.

2. Untuk mengatasi sikap konseli yang tidak berani bertanya kepada guru tentang materi yang belum dipahami, konseli akan mencoba memberanikan diri bertanya kepada guru dengan terlebih dahulu mencatat pertanyaan yang akan ditanyakan. Konseli juga akan meminimalisir rasa grogi ketika di dalam kelas dengan melawan rasa malu yang selalu menyertai setiap mengalami kesulitan dalam memahami materi pelajaran, karena konseli menginginkan untuk berubah, bisa menjadi seseorang yang memiliki penerimaan diri tinggi.

Rencana tindakan dibuat oleh konseli bersama dengan peneliti. Untuk itu peneliti meminta konseli berkomitmen untuk memnjalankan rencana tindakan yang telah dibuatnya sendiri. Konseli menyanggupi untuk melaksanakan rencana tindakan yang telah dibuatnya dengan baik. Konseli ingin berubah menjadi lebih baik sehingga konseli berkomitmen untuk menjalankan rencana tindakan yang telah dibuat dengan sebaik-baiknya.

\section{Hasil konseling:}

Konseli merasa puas dengan hasil konseli. Dengan dibuatnya rencana dan tindakan oleh dirinya sendiri ini akan membuat konseli akan lebih bertanggung jawab terhadap kebutuhannya sebagai seorang pelajar. Konseli berkomitmen untuk terus melaksanakan rencana dan tindakan yang telah dibuatnya.

\section{Post-test}

Setelah melakukan evaluasi dan follow up klien diminta untuk mengisikan skala self acceptance, skala ini sama dengan yang digunakan pada pre- test. Tujuan dari pengisian post-test ini adalah untuk mengetahui apakah terdapat perubahan dari masalah penerimaan diri antara sebelum memperoleh konseling dan sesudah memperoleh konseling. Self acceptance atau penerimaan diri memiliki peranan yang penting dalam interaksi sosial karena penerimaan diri dapat membantu seseorang dalam bersosialisasi dengan orang lain. Tanpa self acceptance, individu cenderung akan sulit bisa menerima orang lain sehingga akan berpengaruh pada perkembangan aktualisasi dirinya. Dengan penerimaan diri yang baik, individu menjadi lebih menyadari siapa dirinya, apa yang menjadi kekurangannya, apa yang menjadi kelebihannya yang ini bisa digunakan untuk menghadapi masalah apa yang sedang dihadapinya, dan tuntutan dalam menjalankan perannya di masyarakat. Self acceptance atau penerimaan diri adalah suatu sikap dimana individu memiliki penghargaan yang tinggi terhadap segala kelebihan dan kekurangan dirinya sendiri tanpa menyalahkan orang lain dan mempunyai keinginan untuk mengembangkan diri secara terus menerus.

Penelitian ini dilakukan untuk mengetahui keefektifan konseling individu realita dalam mengubah self acceptance siswa kelas XI SMA Negeri 15 Bandar Lampung setelah diberikan treatment. Berdasarkan latar belakang masalah, peneliti menentukan layanan konseling individu dengan pendekatan realita sebagai 
treatment untuk mengubah self acceptance rendah pada siswa. Layanan konseling yang diharapkan dapat membantu individu agar mampu menentukan arah hidup yang dipilihnya sendiri, mampu memecahkan masalah yang dihadapinya dan yang paling penting adalah mampu menyesuaikan diri secara positif. Glasser (dalam Corey, 2007: 269) menyebutkan bahwa "mengajarkan tanggungjawab merupakan inti dalam konseling realita." Hal ini dimaksudkan agar konseli dapat menjadi individu yang mandiri dengan memahami keadaan dirinya dan berusaha mengembangkan segala potensiyang dimilikinya dalam menghadapi segala permasalahan hidup. Sesuai dengan pernyataan di atas, berarti konseling ini tepat jika diberikan pada siswa yang sudah diharuskan bisa menghadapi tantangan hidup.

Gambaran self acceptance pada siswa sebelum konseling individu realita menunjukan bahwa terdapat enam anak yang memiliki self acceptance rendah dan memiliki perilaku tidak bisa menerima diri. Perilaku tidak bisa menerima diri ditunjukan dengan sikap seperti pendiam, suka menyendiri di dalam kelas, suka berpikiran negatif terhadap dirinya sendiri, menghindari teman, kurang percaya diri atau minder, serta malu dengan latarbelakang dirinya sendiri. Gambaran self acceptance diperoleh dari hasil wawancara dan skala self acceptance yang diisi oleh masingmasing siswa. Kemudian, keenam siswa tersebut diberikan treatment melalui konseling individu realita. Dari hasil konseling individu yang telah dilakukan, peningkatan self acceptance setiap siswa diukur kembali menggunakan skala self acceptance. Hasil pengisian skala self acceptance setelah mendapatkan konseling individu realita menunjukan bahwa peningkatan tertinggi terdapat pada siswa YPA atau klien pertama dan peningkatan paling rendah terjadi pada klien ke-5. Adanya peningkatan tersebut menunjukan bahwa self acceptance siswa kelas XI SMA Negeri 15 Bandar Lampung dapat ditingkatkan melalui konseling realita.

Kemampuan konselor dalam membangun hubungan interpersonal dalam proses komunikasi konseling merupakan elemen kunci keberhasilan proses konseling. Komalasari, dkk. (2011:267) mengungkapkan “konselor harus mampu menujukan sikap yang selaras dan keaslian (congruence or genuineness), penerimaan tanpa syarat (unconditional positive regard and acceptance), dan pemahaman empati yang tepat (accurate emphatic understanding)". Apabila dalam proses konseling, kondisi dan peran konselor dapat dimunculkan, maka klien pun akan merasa lebih aman dan nyaman dan klien akan menjadi lebih terbuka pada saat proses konseling.

Pada awalnya konseli merasa malu untuk menceritakan dirinya. Hal ini dapat terjadi karena konseli belum merasa nyaman dan percaya dengan konselor. Padahal dalam penelitian ini, konseling realita memandang self acceptance sebagai kondisi yang merupakan bentuk penerimaan individu tentang segala potensi yang dimilikinya, baik itu berupa kelebihan maupun segala kekurangan yang telah melekat pada dirinya sehingga individu tersebut dapat memahami dan menerima dirinya sebagai proses aktualisasi diri. Dalam melakukan konseling realita, konselor sangat memperhatikan aspek-aspek self acceptance untuk mengetahui sejauh mana keberhasilan konselor dalam mengubah penerimaan diri konseli. Pada aspek 
keluasan terkait dengan banyaknya topik yang didiskusikan seperti pendidikan konseli, hobby, penerimaan diri konseli secara fisik yaitu faktor ekonomi konseli. Pada aspek kedalaman, terkait bagaimana cara konselor mengenal lebih dalam konseli dalam beberapa tahapan seperti basa-basi, membicarakan orang lain dan pengungkapan perasaan konseli yang sebenarnya.

Secara keseluruhan, hasil penelitian yang telah dilakukan menunjukan bahwa siswa kelas XI yang menjadi subjek penelitian mempunyai self acceptance rendah karena mereka merasa kurang kasih sayang dan perhatian, terlebih ini karena mereka berasal dari keluarga dengan kondisi ekonomi lemah. Konseling dilaksanakan sesuai dengan prosedur yang telah direncanakan. Walaupun dalam pelaksanaan treatment terdapat beberapa hambatan, namun secara keseluruhan pelaksanaan treatment dapat berjalan dengan baik. Hambatan yang ditemui selama pelaksanaan kegiatan adalah menentukan waktu pertemuan karena klien mempunyai banyak kesibukan dengan kegiatan di sekolah.

Hasil konseling terhadap siswa yang memiliki penerimaan diri rendah memang belum memberikan pengaruh yang besar terhadap penyelesaian secara keseluruhan, namun mampu meningkatkan penerimaan diri siswa khususnya pada 6 siswa yang menjadi sampel dalam penelitian ini. Sesuai dengan judul skripsi ini, yaitu meningkatkan penerimaan diri (self acceptance) melalui konseling realita diharapkan melalui layanan konseling individu tersebut mampu untuk mengatasi masalah rendahnya penerimaan diri pada siswa kelas XI SMA Negeri 15 Bandar Lampung. Sesuai dengan uraian tersebut dapat disimpulkan bahwa konseling realitas dapat mengatasi penerimaan diri rendah, sehingga dapat diketahui bahwa harapan dari penelitian ini tercapai.

\section{KESIMPULAN}

Berdasarkan hasil penelitian tentang mengubah self acceptance siswa kelas XI SMA Negeri 15 Bandar Lampung diperoleh kesimpulan secara umum bahwa self acceptance siswa dapat ditingkatkan melalui konseling individu realita. Adapun kesimpulan khusus diperoleh hasil sebagai berikut: (1) Gambaran self acceptance siswa kelas XI SMA Negeri 15 Bandar Lampung sebelum diberikan konseling individu realita yaitu siswa kelas termasuk dalam kriteria self acceptance rendah dengan persentase sebesar 48\%. (2) Gambaran self acceptance setelah diberikan konseling individu realita yaitu siswa kelas XI SMA Negeri 15 Bandar Lampung dalam kriteria sedang dengan persentase sebesar 64\%. (3) Ada perbedaan self acceptance siswa kelas XI SMA Negeri 15 Bandar Lampung sebelum dan setelah diberikan layanan konseling individu realita.

\section{DAFTAR PUSTAKA}

Arifin, Zainal. 2011. Penelitian Pendidikan Metode dan Paradigma Baru. Bandung: Remaja Rosdakarya 
Arikunto, Suharsimi. 2007. Prosedur Penelitian Suatu Pendekatan Praktik. Jakarta: Rineka Cipta

Azwar, Saifuddin. 2016. Penyusunan Skala Psikologi. Yogyakarta: Pustaka Pelajar

Corey, Gerald. 2010. Teori dan Praktek Konseling \& Psikoterapi. Bandung: Rafika Aditama

Fauzan, Lutfi. 2014. Pendekatan-Pendekatan Konseling individual. Malang: Elang Mas

Gibson, R. L \& Mitchell, M. H. 2011. Bimbingan dan Konseling. Yogyakarta: Pustaka Pelajar

Hjelle, L. A \& Zeigler, D. J. (2012). Personality Theories : Basic Assumptions, ResearchAnd Application. Tokyo : MC Graw Hill

Hurlock, E. B. 2010. Psikologis Perkembangan : Suatu Pendekatan Sepanjang RentangKehidupan. Jakarta : Erlangga

Jersild, A. T. 2015. The Psychology of Adolescence. New York: MC Millan Company.

Meilinda, Endah. 2013. E-Journal Psikologi. http://ejournal.psikologi.fisip-unmul.org [diunduh 4/01/2018]

Moleong, Lexy J. 2007. Metodologi Penelitian Kualitatif. Bandung: Remaja Rosdakarya

Mugiarso, Heru dkk. 2014. Bimbingan dan Konseling. Semarang: UNNES Press.

Nazir, Moh. 2003. Metode Penelitian. Bogor: Ghalia Indonesia.

Nelson, Richard dan Jones. 2011. Teori dan Praktik Konseling dan Psikoterapi. Yogyakarta: pustaka Pelajar

Nurviana, Eki Vina dkk. 2010. http://eprints.undip.ac.id/10783/1/jurnal.pdf [diunduh 20/01/2018]

Konseling dan Psikoterapi. Yogyakarta: Pustaka Pelajar.

Prayitno. 2014. Layanan Bimbingan dan Konseling. Padang: Universitas Negeri Padang

Prayitno, dan Erman Aamti. 2010. Dasar-Dasar Bimbingan dan Konseling. Jakarta: Rineka Cipta

Putri, Novia Pratama. 2011. Upaya Mengatasi Kepercayaan Diri Rendah Kelayan Melalui Konseling Perorangan Dengan Pendekatan Realita (Studi Kasus Pada Tiga Kelayan Di Panti Asuhan Al-Huda Semarang)

Schultz, D. 2011. Psikologi Pertumbuhan : Model-model Kepribadian Sehat. Alih bahasa : Yustinus. Yogya : Kanisius

Supriyo. 2008. Studi Kasus Bimbingan Konseling. Semarang: CV. Nieuw setapak

Surya, Moh. Dan Djumhur. 2010. Bimbingan dan Penyuluhan di Sekolah (Guidance and Counseling) Bandung: Angkasa

Sutadipura, Balnadi. 2014. Kompetensi Guru dan Kesiapan Mental. Bandung: Angkasa Willis, Sofyan S. 2004. Konseling Individual (Teori dan Praktek), Bandung: Alfabeta. 